\title{
PRELIMINARY U/TH DATING AND THE EVOLUTION OF GYPSUM CRYSTALS IN NAICA CAVES (MEXICO)
}

\section{PREDHODNI REZULTATI DATIRANJA Z METODO U-TH IN RAZVOJ SADRINIH KRISTALOV V JAMI NAICA (MEHIKA)}

\author{
Laura SANNA ${ }^{1, *}$, Paolo FORTI ${ }^{2}$ \& Stein-Erik LAURITZEN ${ }^{1,3}$
}

\begin{abstract}
UDC 551.435.84(72):553.635

Laura Sanna, Paolo Forti \& Stein-Erik Lauritzen: Preliminary $U / T h$ dating and the evolution of gypsum crystals in Naica caves (Mexico).

The origin and the evolution of giant selenite crystals in Naica caves, together with the understanding of their growth mechanisms, is one of the aims of the international multidisciplinary research, called the "Naica Project". In this context, the exact timing of when the gypsum nucleation started and whether its growth has been constant over time, have been investigated. The preliminary data obtained with the U-Th disequilibrium method show significant differences in ages for gypsum (between $191 \pm 13 \mathrm{kyr}$ for one of the Ojo de la Reina cave crystals and $57 \pm 1.7 \mathrm{kyr}$ for the base of Espadas cave's spar) and have produced a coarse chronological interval of growth. The crystal depositional rates vary from 0.56 to $1.22 \mathrm{~mm} / \mathrm{kyr}$, in excellent agreement with the laboratory tests for gypsum deposition under present conditions performed in the deepest part of the mine. These results are also consistent with a multistage precipitation started at different times in the Naica caves (first in caves at the upper level, where gypsum was subsequently dissolved, and only later in the deeper part of the aquifer under stable conditions) and allow us to improve the knowledge on the speleogenetic evolution of these caves.

Keywords: U-Th dating, gypsum speleothems, mine caves, crystal growth rate, Naica, Mexico.
\end{abstract}

Izvleček

UDK 551.435.84(72):553.635

Laura Sanna, Paolo Forti \& Stein-Erik Lauritzen: Predhodni rezultati datiranja $z$ metodo $U$-Th in razvoj sadrinih kristalov v jami Naica (Mehika)

Izvor, razvoj in mehanizmi rasti velikih selenitnih kristalov v jamah Naica, so del raziskav v okviru mednarodnega projekta „Naica«. V okviru teh smo določali natančen čas začetka nukleacije sadre in stalnost rasti kristalov v času. Prvi podatki datiranj $\mathrm{z}$ uran-torijevo metodo kažejo na pomembne razlike $\mathrm{v}$ starosti kristalov sadre ( med $191 \pm 13$ ky za kristale v jami Ojo de la Reina in $57 \pm 1.7$ ky v korenu kristala Espada) in veliko časovno obdobje rasti. Hitrost rasti kristalov je med 0,56 in $1,22 \mathrm{~mm} / \mathrm{ky}$, kar se odlično ujema $\mathrm{z}$ eksperimentalnimi rezultati v trenutnih pogojih v najglobljem delu rudnika. Rezultati podpirajo tezo o več stopenjskem izločanju kristalov (prvotno $\mathrm{v}$ jamah gornjega nivoja, kjer je bila sadra naknadno raztopljena in kasneje $\mathrm{v}$ stabilnih razmerah globoko v vodonosniku) in omogočajo nove interpretacije speleogeneze na obravnavanem območju.

Ključne besede: Datiranje z metodo U-Th, sadra, jame v rudniku, hitrost rasti kristalov, Naica, Mehika.

\footnotetext{
${ }^{1}$ GEO, Department of Earth Sciences, Bergen University, Norway, e-mail: speleokikers@tiscali.it

${ }^{2}$ Earth and Geological Environmental Sciences, University of Bologna, Italy

${ }^{3}$ Department of Plant and Environmental Sciences, University of Ås, Norway

Received/Prejeto: 22.9.2010
} 


\section{INTRODUCTION}

Giant selenite crystals discovered inside natural caves in the Naica Mine (State of Chihuahua, Northwest Mexico) are among the most interesting geological revelations of recent years (Badino \& Forti 2005). In 2006, a multidisciplinary research project was started by Speleoresearch \& Film from Mexico with the co-operation of La Venta Exploring Team (Forti 2006). The aim of this project is to investigate the origin and the evolution of these gypsum crystals, together with the understanding of their growth mechanisms, and the kind of relationships existing between the ore bodies and these crystals. Even though some of this research has already brought important scientific results (Bernabei et al. 2009), e.g. the detailed survey of Cueva de los Cristales (Crystals Cave) (Badino et al. 2009), the comprehension of the genesis and the evolution of the caves in the Naica Mine (Bernabei et al. 2007; Forti et al. 2007), and the minerogenetic environ- ments (Forti et al. 2008, 2009a, b; Garcia-Ruiz et al. 2007; Garofalo et al. 2007; Panieri et al. 2008), the exact timing when the nucleation started and whether growth has been constant over time was still to be investigated. For this reason in 2006 an underground laboratory was set up at the -590 Level in the Naica Mine with the goal of investigating the crystal growth rate at the present conditions (Forti \& Lo Mastro 2008), and in 2007 some selenite samples from the three main caves (Cueva de los Cristales, Ojo de la Reina and Cueva de las Espadas) were collected for dating purposes. A $\mathrm{U}$ and Th extraction procedure using isotope dilution for radiometric dating intent of gypsum has been developed in the U-series Dating Laboratory of Bergen University (Sanna et al. 2010). This paper shows preliminary age results on the gypsum Naica samples and their relationship with the local evolution of these crystallizations.

\section{EXPERIMENTAL OBSERVATIONS}

Besides the wide desolate landscape around the Sierra de Naica (Chihuahua, Mexico), small amazing geological secrets (Foshag 1927; Shagun 2001; London 2003) are hidden inside this anticline structure of Cretaceous carbonate rocks (Megaw et al. 1988). During the last century, the depths of this NW-oriented mountain have been penetrated by several kilometres of mine galleries, and the extensive silver exploitation has intercepted some natural cavities at different levels inside the mountain (Fig. 1), most of which host huge selenite crystals grown in underwater conditions (Forti et al. 2007). The gypsum deposition occurred in three different environments (deep phreatic, epiphreatic and aerate) starting in the upper part of the mountain profile, where the water temperature first decreased below $59^{\circ} \mathrm{C}$ (Forti et al. 2009a). Gypsum growth is controlled by the dynamic evolution of a stable supersaturated flow system and went on until some 25 years ago, when the water eduction for mine exploitation purposes caused the lowering of the watertable from $-130 \mathrm{~m}$ to $-760 \mathrm{~m}$, thus dewatering the caves (Garofalo et al. 2007). All these caves developed along the main faults, which guided the uplift of these thermal fluids (Forti \& Sanna 2010). Fluids still rise in the mine galleries of level -590 and have a temperature of $51-54^{\circ} \mathrm{C}$.

The most famous explored cavities in the Naica Mine are Cueva de los Cristales (Crystals Cave), Ojo de la Reina (Queen's Cave) and Cueva de las Espadas
(Swords Cave), and all of those host euhedral gypsum crystals for which post-depositional alteration and open systems - necessary conditions for dating purposes - are excluded.

Cueva de los Cristales is a big chamber of about $30 \mathrm{~m}$ diameter and $20 \mathrm{~m}$ height, intercepted by the mine galleries at the -290 Level (Fig. 2b), that hosts a network of the largest known, prismatic shaped, gypsum single crystals in the world (Fig. 2a) (the largest measures $11 \mathrm{~m}$ in length and $1 \mathrm{~m}$ in diameter) (Badino et al. 2009). From Cueva de los Cristales we sampled two broken crystals (N1 and N07) found on the cave floor. The dated subsamples were collected from slices cut perpendicularly to their elongation axis: a) N07-10 was drilled $13 \mathrm{~cm}$ from the outer surface on a slide about $40 \mathrm{~cm}$ in diameter on the N07 crystal (Fig. 2); b) N1 was collected $5 \mathrm{~cm}$ from the outer surface on a slide about $20 \mathrm{~cm}$ in diameter on the N1 crystal (Figure 2d).

Ojo de la Reina is a small cave consisting of a narrow fracture discovered close to Crystals Cave (Fig. 2f). It is completely filled by transparent and pinacoid-shaped crystals grown in several steps (Fig. 2e), as demonstrated by black sulphur layers in the 4-m high exposed crystal wall below the entrance (Fig. $2 \mathrm{~g}$ ). The Reina sample (N01-1) is composed of loosely bound laminae of completely transparent gypsum, taken at the bottom of this crystal wall almost at the contact with the dolomitic limestone: therefore this sample should represent to the 


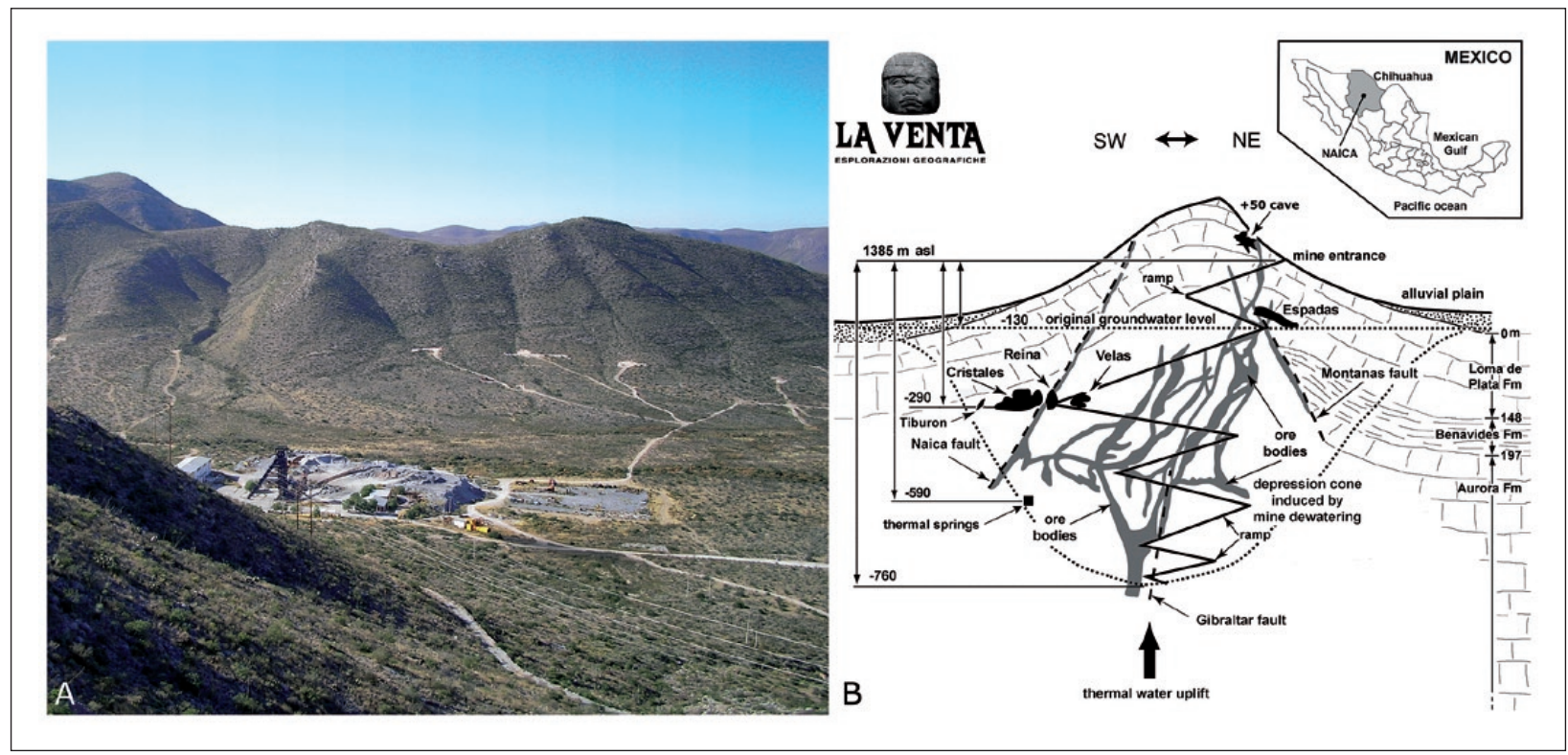

Fig. 1: a) The desert landscape of the Sierra de Naica in a general view of the south-western side of the anticline structure (Photo: L. Sanna, La Venta \& S/F Archives); b) Sketch of the Naica mine with the locations of the main natural cavities - not to scale (after Badino \& Forti 2007, modified).

very beginning of the gypsum deposition in the -290 Level. Actually, due to the disposition of the cave (a subvertical fracture) and of the crystals, one cannot be sure that the sample was collected just in the inner (oldest) core of the crystal bulk. Thus the gypsum deposition date may somehow appear older than the age obtained from this sampling.

Cueva de las Espadas is a distinct sub-horizontal conduit at the -120 Level where single crystals up to $2 \mathrm{~m}$ in length occur, while other, smaller, crystals completely cover its walls (Fig. $2 \mathrm{~h} \mathrm{\&} 2 \mathrm{j}$ ). This cave develops along a fault, and there are clear evidences of a complex speleogenesis of hydrothermal and meteoric behaviour (Panieri et al. 2008). The Espadas sample is a subaqueous speleothem found just in the bottom of the cave. Its nucleus consists of a prismatic gypsum crystal enclosed inside two layers of white acicular aragonite crystals (pointing to the partial emersion of the cave), alternated with two layers of gypsum macrocrystals (Fig. 2i). The surface of the speleothem was covered by a thin layer of hazelbrown calcite and by scarcely cemented clay-silty deposits (Forti 2007). Three different subsamples were collected: a) a gypsum subsample drilled about $6 \mathrm{~cm}$ from the core (ESP1-1); b) a 2-mm thick subsample of aragonite layer in contact with the gypsum core (ESP1-2); c) a 1-mm thick calcite cover (Fig. 2k).

\section{EXPERIMENTAL DATING OF GYPSUM}

The U-Th method is the most widely-used dating technique applied to carbonate speleothems (Walker 2008), but none of the published papers indicate that this method is suitable for dating of gypsum, due to its very low $\mathrm{U}$ content and owing to the difficulty in separation and purification of the samples and the high solubility of sulphate that produces post-depositional alteration (Sancho et al. 2004). For these reasons some authors prefer the Electron Spin Resonance technique (Mathew et al. 2004; Ikeda \& Ikeya 1991). However, few studies have been published on the determination of U/Th ratio in a variety of gypsum samples using different procedures, such as the $\alpha$-spectrometric technique (Hendy et al. 1979), isochron dating method (Luo \& Ku 1991), thermal ionization mass spectrometry (TIMS) (Peng et al. 2001) and inductively coupled plasma mass spectrometry (ICP-MS) (Gamble 2008). There is only one documented test on single gypsum speleothem dating, but the ensuing age showed a large standard error and thus has been regarded as unreliable (Goede et al. 1990). Although the high precision analysis of $\mathrm{U}$ isotopes with multi-collector ICP-MS (MC-ICP-MS) has been well established (Becker 2003), TIMS has been a widely employed technique for accomplishing the highest accuracy and precision of isotope ratios. Only recently, several studies have focused on the capability of MC-ICP-MS using isotope dilution (ID) for U/Th activity ratios in samples with extremely low U content ( $\mathrm{Lu} 2009$ ), such as in the gypsum crystals of Naica.

Despite the fact that the first chronological data on the giant selenite crystals of Naica were obtained with the traditional TIMS analytical approach (Lauritzen et 

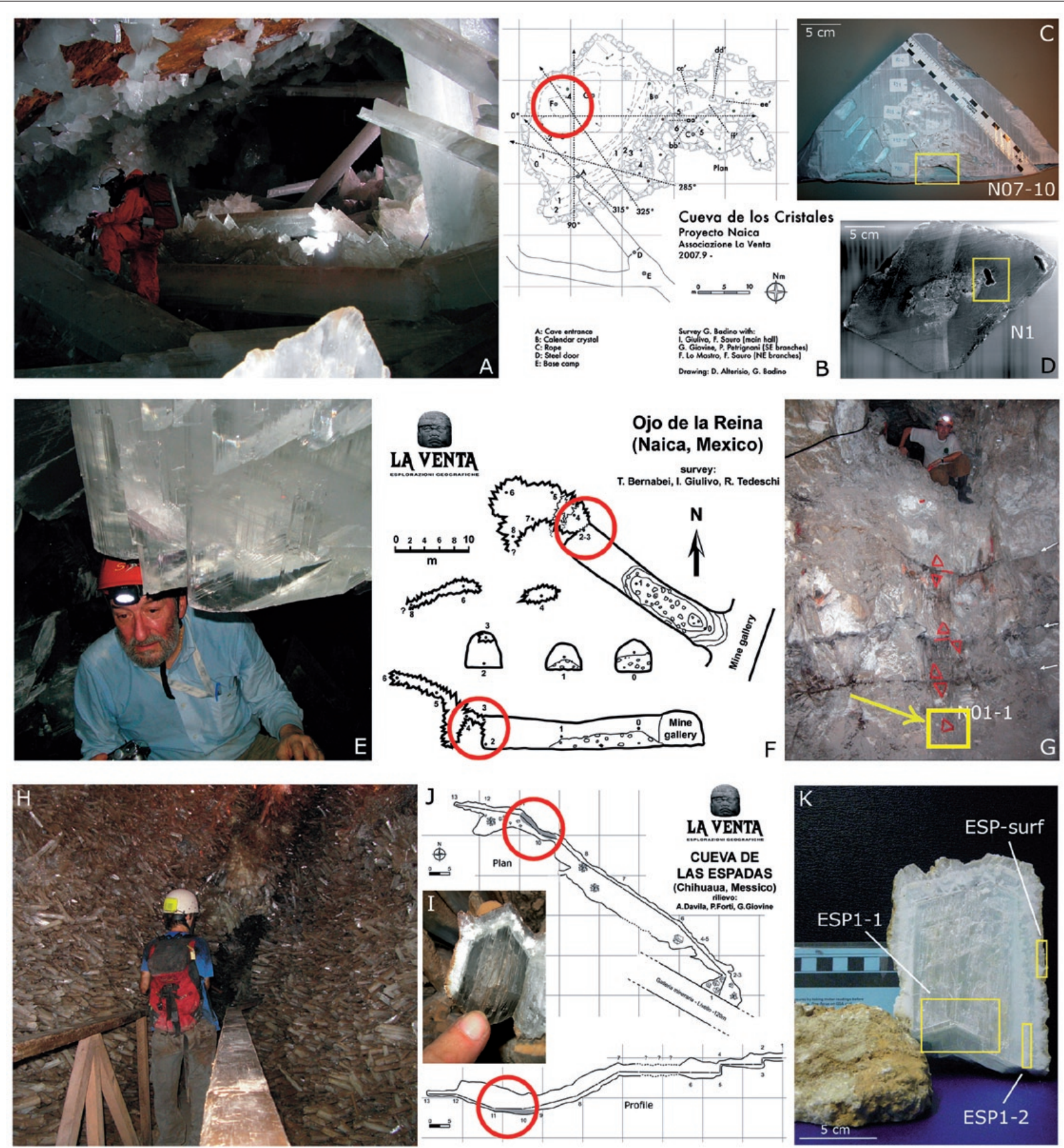

Fig. 2: The three main caves of Naica Mine. a) View from the west of the giant selenite crystals (caver for scale) of Cueva de los Cristales. The two samples of already broken crystals ( $c$ and d) have been found on the north-western side of the cave floor, red circle in the map (b). e) Well-formed transparent and pinacoid-shaped gypsum crystals hosted inside the narrow fracture of Ojo de la Reina and (g) the 4- $m$ high exposed crystal wall below the entrance, point 2 in the survey $(f)$. The white arrows indicate the black sulphur layers. $h$ ) The gypsum speleothems on the wall of Cueva de las Espadas and (i) an euhedral gypsum crystal covered by a layer of carbonate. The dated spar $(k)$ was collected on the floor of a small cave lake, corresponding to the grey area in the map (j). Yellow squares show dated subsamples (Photos: La Venta \& S/F Archives).

al. 2007), this method was time-consuming and expensive, and the results were not satisfying (very low $U$ concentration), so a simpler method with the TRU Resin separation for high resolution ICP-MS detection has been adopted (Sanna et al. 2010). After determining the solubility of gypsum in different solutions, to optimize 
gypsum digestion, and then increasing the amount of the sample up to $5 \mathrm{~g}$ to have a greater quantity of actinides, a mixed procedure (after Hellstrom 2003 with several modifications) has been tested using the semi-quantitative $\mathrm{U}$ concentration provided by TIMS preliminary analysis, to balance the isotopic tracers (spike). This quantity is one tenth of the normal spike amount usually used for carbonate analyses, since overspiked samples cannot be dated. In the first experiment, with a $5 \mathrm{~g}$ sample and $10 \mu \mathrm{L}$ spike, the yield was very bad. Almost all actinides were lost during the process, but the spiking level was quite good. Contamination of ${ }^{232} \mathrm{Th}$ was also very high. In the following experiment, prior to further raising the quantity of the gypsum sample, the acid concentration was adjusted to amplify the uranium and thorium purification, but during ICP-MS acquisition no actinide signal occurred. Finally, after increasing the selenite amount up to $10 \mathrm{~g}$ (in spite of a loss in the stratigraphic resolution), the procedure worked satisfactorily.

For each dating, gypsum subsamples were separated by means of a cutting disk for dentists, from a $20 \times 8 \mathrm{~mm}$ thick rod (cut along the elongation axis of crystal), and the gypsum powder was dissolved completely by digestion with $600 \mathrm{~mL}$ of $1 \mathrm{M} \mathrm{HNO}_{3}$. The spike was added prior to $\mathrm{U}$ and $\mathrm{Th}$ purification. After centrifugation, the small insoluble residue was discarded, and the separation of actinides was performed using a preconditioned TRU Resin ${ }^{\circ}$. Each sample was loaded into its own columns. The $\mathrm{U}$ and Th were eluted by $0.1 \mathrm{M} \mathrm{HCl}-0.2 \mathrm{M} \mathrm{HF}$. Afterwards, the $\mathrm{U}$ and $\mathrm{Th}$ fractions were dried.

In order to carry out the isotopic analysis the actinides dried fraction was dissolved in $2 \% \mathrm{v} / \mathrm{v} \mathrm{HNO}_{3}$ : the isotopic measurements were performed on a Nu Plasma HR multicollector ICP-MS with a U-Pb collector block at the Department of Geology, University of Oslo. Analyses were done in dry plasma using a DSN-100 desolvating nebuliser with a sample uptake rate of $0.1 \mathrm{~mL} / \mathrm{min}$ (Sanna et al. 2010).

\section{EXPERIMENTAL ACCRETION OF GYPSUM}

Another method to define the age of the largest crystals is to measure the present rate of growth, but 25 years ago their accretion stopped due to mine dewatering that dried up the caves. Thermal water $\left(51{ }^{\circ} \mathrm{C}\right)$ is now spilling inside the mine galleries only $300 \mathrm{~m}$ below the known caves at the -590 Level (Forti \& Lo Mastro 2008).

Within Naica caves the principal genetic mechanism for the giant crystals was ruled only by the solubility disequilibrium between anhydrite and gypsum under supersaturated aqueous solution within a temperature range $55-58^{\circ} \mathrm{C}$ (Garcìa Ruiz et al. 2007; Panieri et al. 2008). To restore these conditions the contact between water and air should be avoided, and both evaporation and temperature losses should be kept as low as possible: for this purpose a specific device was planned and realized (Forti \& Lo Mastro 2008). In 2006 a vessel (the main component of this apparatus) was placed in a dangerously hot location where original thermal water with a temperature of more than $51{ }^{\circ} \mathrm{C}$ is still dripping out from the mine wall rock and $100 \%$ relative humidity is present. It was designed to stay there for at least 2 years (Fig. 3). Inside the vessel 11 prismatic polycrystalline samples of Messinian gypsum from the Emilia-Romagna formation (Italy) have been suspended to act as crystalli-

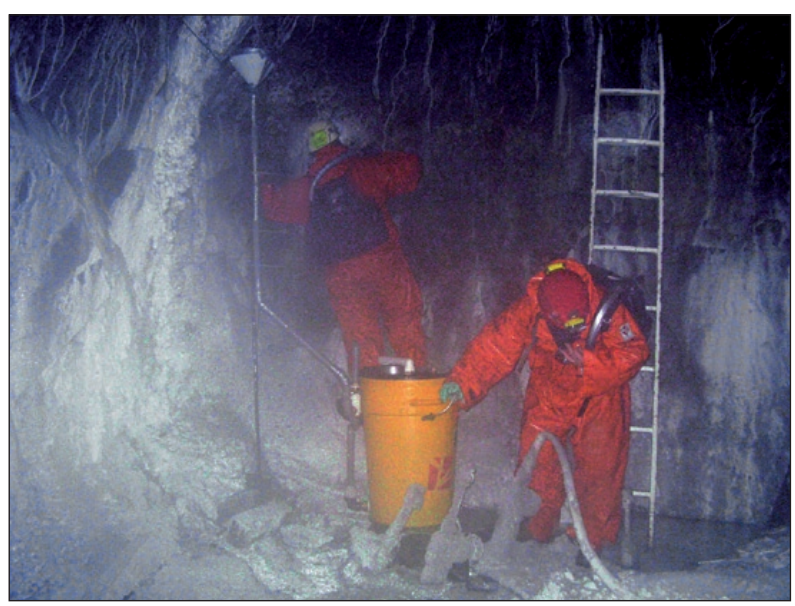

Fig. 3: The experimental laboratory: the vessel was placed in a place with a temperature of more than $51^{\circ} \mathrm{C}$ and relative humidity of 100\% (Photo: L. Sanna, La Venta \& S/F Archives).

zation support in thermal water coming from the spring in the mine gallery. The average surface of the tablets is $66 \mathrm{~cm}^{2}$. All the tablets were carefully measured and weighed before their use.

\section{RESULTS}

\section{ANALYSES OF THE NAICA CRYSTALS}

According to Sanna et al. (2010) the giant crystals display significant differences in ages (Tab. 1). The core of the broken giant selenite from Cristales began to grow at an imprecise age between $106-260 \mathrm{kyr}$ ago, while the first $\mathrm{U} / \mathrm{Th}$ dating was made by TIMS technique some $5 \mathrm{~cm}$ 
Tab. 1: Uranium concentration, measured $U$ and Th activity ratios and ages of subsamples from Naica crystals (modified after Sanna et al. 2010). For the subsample locations see Fig. 2.

\begin{tabular}{|c|c|c|c|c|c|c|c|c|c|c|c|c|}
\hline ID Lab & ID sample & Cave & $\begin{array}{r}U \\
(p p m)\end{array}$ & ${ }^{234} U /{ }^{238} U$ & ${ }^{230} \mathrm{Th} /{ }^{334} \mathrm{U}$ & ${ }^{230} \mathrm{Th} /{ }^{232} \mathrm{Th}$ & Age, kyr & $2 \sigma^{+}$ & $2 \sigma^{-}$ & Corr.age & $2 \sigma^{+}$ & $2 \sigma^{-}$ \\
\hline 850 & N01-1 & Ojo & 0.001 & $1.05741 \pm 0.0129$ & $0.87149 \pm 0.0133$ & $7 \pm 0.49$ & 213.7 & 12.53 & 11.03 & 191.018 & 13.75 & 12.5 \\
\hline 788 & N1 & Cristales & 0.004 & $0.76927 \pm 0.0020$ & $0.30282 \pm 0.0049$ & $10 \pm 0.17$ & 40.071 & 0.82 & 0.81 & 34.544 & 0.82 & 0.81 \\
\hline $853 \mathrm{~b}$ & N07-10 & Cristales & 0.000 & $1.33974 \pm 0.0933$ & $0.82823 \pm 0.1406$ & $12 \pm 1.85$ & 168.838 & 101.14 & 51.8 & 158.526 & 101.64 & 51.96 \\
\hline 858 & ESP1-1 & Espadas & 0.046 & $2.36105 \pm 0.0109$ & $0.44666 \pm 0.0773$ & $19 \pm 18.62$ & 60.457 & 0.07 & 0.07 & 57.01 & 1.77 & 1.77 \\
\hline $863 \mathrm{~b}$ & ESP1-2 & Espadas & 0.163 & $2.97474 \pm 0.0294$ & $0.13186 \pm 0.0334$ & $29 \pm 7.43$ & 15.209 & 4.14 & 4.02 & 14.491 & 4.15 & 4.03 \\
\hline 796 & ESP-surf & Espadas & 0.2 & $3.42787 \pm 0.0067$ & $0.24131 \pm 0.00289$ & $949 \pm 20$ & 7.874 & 0.04 & 0.04 & 7.863 & 0.04 & 0.04 \\
\hline
\end{tabular}

${ }^{1}$ Correction for detrital ${ }^{230} \mathrm{Th}$ contamination, assuming "world mean" initial ${ }^{230} \mathrm{Th} /{ }^{232} \mathrm{Th}$ of 1.5 (Richards \& Dorale, 2003)

below the surface of another broken crystal and gave an age of $34.5 \pm 0.8 \mathrm{kyr}$ (Lauritzen et al. 2007). The Ojo de la Reina sample is the oldest crystal analysed ( $191 \pm 13 \mathrm{kyr})$. The depositional sequence of the Espadas speleothem shows a gypsum core $57 \pm 1.7 \mathrm{kyr}$ in age, covered by the aragonite layer dated to $14.5 \pm 4$ kyr and finally a $7.8 \pm 0.04$ kyr old calcite surface.

\section{CURRENT SPELEOTHEM GROWTH AT THE -590 LEVEL}

After six months gypsum crystals developed showing no trace of calcium carbonate. This demonstrates that as reported by Forti \& Lo Mastro (2008), the measured increase in weight $(\Delta w)$ in the first four recovered tablets (covering an interval of 485 days) is in good agreement with the time of immersion that they spent inside the vessel (Fig. 5).

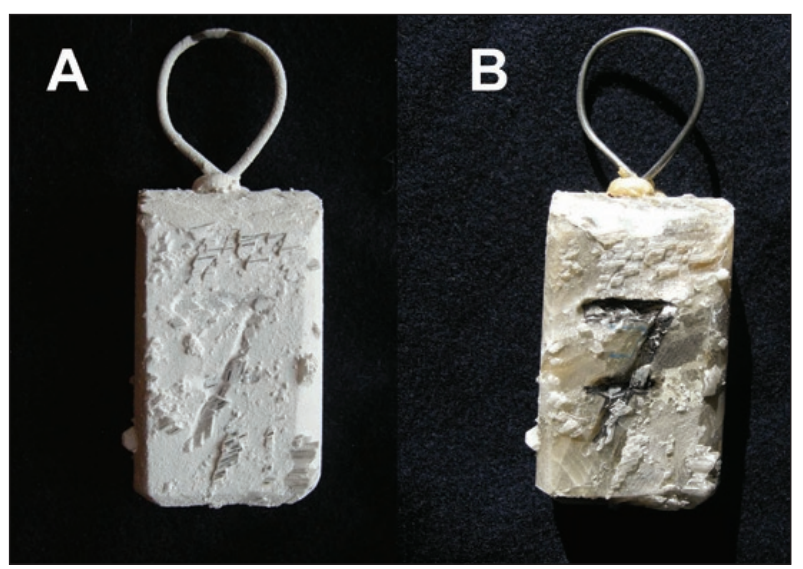

Fig. 4: a) One of the gypsum tablets recovered in February 2010: the presence of a calcite microcrystalline layer covering the whole tablet is evident; $b$ ) the same tablet after the chemical removal of the calcite.

For about two years, no scientific expedition to Naica was allowed, and in February 2010 the vessel was found open and all the remaining tablets partially covered by a thin calcite layer (Fig. 4). It is possible to state that in 2009 the laboratory at -590 Level was visited twice (in September and December, respectively) by two different filming teams: therefore the opening of the vessel surely occurred on one of these two occasions, but it has not been possible to fix the exact date the vessel was left open. The scarce amount of calcium carbonate covering the tablets suggests that the contact between the water in the vessel and the atmosphere was induced very recently, thus December 2009 is the most probable time. As expected (Forti et al. 2008), the contact with the atmosphere caused a rather immediate supersaturation with respect to calcium carbonate and the development of a microcrystalline crust over the tablets. Even if the termination of gypsum deposition was fast, it was not synchronous with the calcite

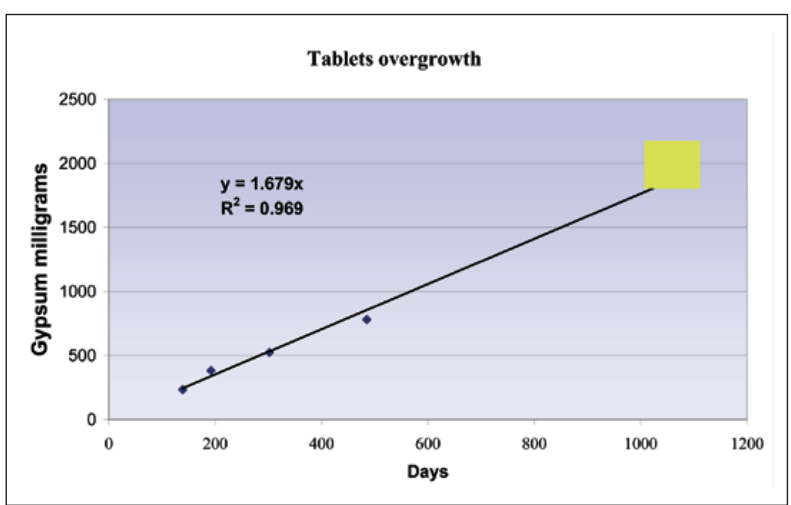

Fig. 5: Correlation between measured gypsum overgrowth and time (data from table 2). The yellow square marks the uncertainty of the data in which the vessel was open (September or December 2009). The equation and the correlation line were obtained by using only the data from the first 4 tablets.

precipitation, thus a small amount of calcium carbonate was trapped within the last accretion layers of the 
Tab. 2: Growth data of gypsum tablets and the relative average deposition correction for temperature effects on the supersaturation. The tablets recovered in February 2010 stopped their growth when the vessel was left open, probably in December 2009, and the calcite trapped in the gypsum crystals slightly contributes to increase their weight.

\begin{tabular}{|c|c|c|c|c|c|c|c|c|c|}
\hline $\begin{array}{l}\text { ID } \\
\text { Sample }\end{array}$ & $\begin{array}{c}\text { Weight (g) at } \\
18 / 11 / 06\end{array}$ & Date & N. Days & $\begin{array}{r}\text { Weight } \\
(g)\end{array}$ & $\Delta w$ & $\begin{array}{c}\Delta w / y r \\
(g / y r)\end{array}$ & $\begin{array}{r}\Delta h / y r \\
(\mathrm{~mm} / \mathrm{yr})\end{array}$ & $\mathrm{mM} / \mathrm{cm}^{2} \mathrm{~s}$ & $\begin{array}{r}{ }^{1} \text { Corr. } \\
\mathrm{mM} / \mathrm{cm}^{2} \mathrm{~s}\end{array}$ \\
\hline 5 & 105.130 & $27 / 3 / 2007$ & 139 & 105.364 & 0.234 & 0.614 & 0.040 & $1.71 \mathrm{E}-9$ & $1.56 \mathrm{E}-10$ \\
\hline 2 & 109.969 & $18 / 5 / 2007$ & 191 & 110.351 & 0.382 & 0.730 & 0.048 & $2.04 E-9$ & $1.85 \mathrm{E}-10$ \\
\hline 6 & 110.742 & $6 / 9 / 2007$ & 302 & 111.263 & 0.524 & 0.633 & 0.041 & $1.77 \mathrm{E}-9$ & 1.61E-10 \\
\hline 3 & 107.209 & $28 / 2 / 2008$ & 485 & 107.989 & 0.780 & 0.587 & 0.038 & $1.64 \mathrm{E}-9$ & 1.49E-10 \\
\hline 1 & 108.833 & $03 / 02 / 2010(03 / 12 / 2009)$ & 1103 & ${ }^{*} 110.710$ & 1.877 & 0.604 & 0.040 & $1.73 \mathrm{E}-9$ & $1.58 \mathrm{E}-10$ \\
\hline 4 & 104.881 & $03 / 02 / 2010(03 / 12 / 2009)$ & 1103 & *106.884 & 2.003 & 0.738 & 0.048 & $1.85 \mathrm{E}-9$ & $1.68 \mathrm{E}-10$ \\
\hline 7 & 98.648 & 03/02/2010 (03/12/2009) & 1103 & $* 100.858$ & 2.210 & 0.711 & 0.047 & 2.04E-9 & $1.86 \mathrm{E}-10$ \\
\hline 8 & 99.323 & 03/02/2010 (03/12/2009) & 1103 & ${ }^{*} 101.312$ & 1.989 & 0.640 & 0.041 & $1.84 \mathrm{E}-9$ & 1.67E-10 \\
\hline 10 & 107.627 & $03 / 02 / 2010(03 / 12 / 2009)$ & 1103 & ${ }^{*} 109.505$ & 1.878 & 0.600 & 0.038 & $1.73 \mathrm{E}-9$ & $1.58 \mathrm{E}-10$ \\
\hline 11 & 109.445 & 03/02/2010 (03/12/2009) & 1103 & *111.337 & 1.892 & 0.608 & 0.039 & $1.75 \mathrm{E}-9$ & 1.59E-10 \\
\hline 9 & 104.867 & Lost & -- & -- & -- & -- & -- & -- & --- \\
\hline Average & & & & & & 0.647 & 0.042 & $1.81 \mathrm{E}-9$ & $1.65 \mathrm{E}-10$ \\
\hline
\end{tabular}

${ }^{1}$ Correction factor for temperature lowering with respect to caves (from 57 to $51^{\circ} \mathrm{C}$ ): $1 / 11$

${ }^{*}$ Weights obtained after the chemical removal of $\mathrm{CaCO}_{3}$

gypsum crystals. At any rate this event was fast enough to allow the use of these six tablets also, after the chemical removal of the calcite crust, at least to validate the accretion data obtained by the first four tablets. In fact (see Fig. 5), all six obtained values are only slightly

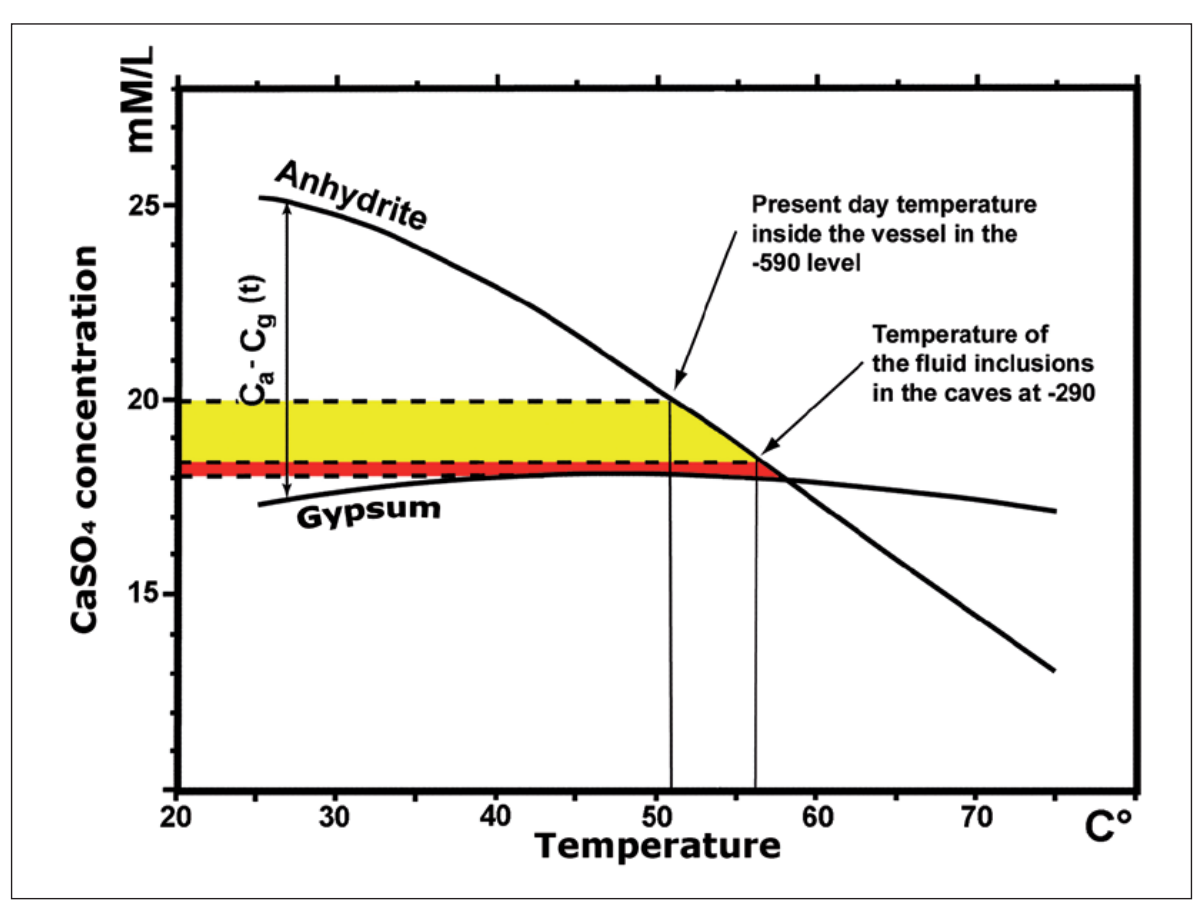

higher than those predicted by the trend line based on the first four, unperturbed, values.

The rate of growth for a giant crystal, as derived from gypsum tablets accretion data, can be calculated by converting the gypsum density in lateral accretion using the experimental average deposition $(0.647 \mathrm{~g} / \mathrm{yr})$ (Tab. 2); thus the average yearlydeposition corresponds to $0.0097 \mathrm{~g} / \mathrm{cm}^{2} \mathrm{yr}$, which is equivalent to an average linear growth rate of $0.042 \mathrm{~mm} / \mathrm{yr}$ or $0.058 \mathrm{mM} / \mathrm{cm}^{2} \mathrm{yr}$.

Fig. 6: Water anhydrite-gypsum solubility as a function of the temperature in the present-day sulphate concentration conditions at Naica mine: the temperature inside the vessel is lower than that which characterized the caves during growth of crystals $\left(51{ }^{\circ} \mathrm{C}\right.$ instead of $57^{\circ} \mathrm{C}$ ). This parameter affects the growth rate with a factor of about 10 (modified after Garcia-Ruiz et al. 2007). 
At any rate, this value cannot be directly used to evaluate the age of the largest crystals, because a fundamental parameter affecting the crystal growth rate has not yet been considered: the temperature inside the vessel. In fact the present temperature inside the device is lower than that which characterized the caves during the growth of their giant crystals: $51{ }^{\circ} \mathrm{C}$ in the presentday thermal spring instead of $57^{\circ} \mathrm{C}$ in the past inside the caves (Garofalo et al. 2010). The anhydrite/gypsum solubility difference is $0.2 \mathrm{mM} / \mathrm{L}$ at $57^{\circ} \mathrm{C}$, whereas it increases to a value of $2.2 \mathrm{mM} / \mathrm{L}$ at $51{ }^{\circ} \mathrm{C}$ (Fig. 6). By taking into consideration only the temperature effect over the supersaturation on the evaluation of the real speed of growth for giant crystals (correction factor $0.2 \mathrm{mM} / \mathrm{L} / 2.2 \mathrm{mM} / \mathrm{L}=1 / 11$ ) the value of the average deposition at that time should be $5.18 \times 10^{-3} \mathrm{mM} / \mathrm{cm}^{2} \mathrm{yr}$ or $0.0037 \mathrm{~mm} / \mathrm{yr}$, giving a growing age of the largest crystals of about $245,000 \mathrm{yr}$, which is fairly close to that obtained by the MC-ICP-MS U/Th dating, with a corresponding rate for $13 \mathrm{~cm}$ of accumulation between 0.001 and $0.005 \mathrm{~mm} / \mathrm{yr}$ (Sanna et al. 2010), but in coarse agreement with the first available absolute date $(600,000$ years) obtained by TIMS measurements, with an average growth of $1.447 \mathrm{~mm} / \mathrm{kyr}$ (Lauritzen et al. 2007).
However the extrapolated data from the first TIMS measurement suffer from a rather large uncertainty, because they are related to crystal growth during a period (the last 40,000 years) in which the groundwater level inside the Naica ridge started oscillating as strong differences in the physico-chemical (mainly temperature and salinity) parameters of the fluid inclusions seem to indicate (Garofalo et al. 2010).

Further, it must be noted here that other second order factors exist in the experimental laboratory, with respect to the natural caves, which may partially justify these differences. Significant parameters may be the ionic effect due to salinity variation, the evaporation that affects the supersaturation value (the consequence of which may influence the growth rate for no more than 3-4\%) and, finally, the flow effect due to water renewal that in the vessel is about 1-2 minutes, but in the Cueva de los Cristales probably lasted from 100 to 1000 times more. The result of this last parameter has not been evaluated, but it may have affected the growth rate even more than the first two (Forti \& Lo Mastro 2008). On the basis of the present available data on the crystal rate of growth, one can estimate the age of the oldest crystals in the Naica mine to converge to a value close to 300,000 years.

\section{DISCUSSION}

On the basis of the preliminary assessment of the ages of the giant selenite crystals hosted in the Naica caves, and of the growth rate evaluation from the experimental laboratory data, it is now possible to reconstruct the coarse minerogenetic sequence of gypsum deposition stages (Fig. 7). The first speleogenetic step was performed by hydrothermal fluids and was common to all the caves; later, the uplifting water became supersaturated with respect to gypsum and the nucleation of huge selenite speleothems started very slowly with minor differences among the various hypogenic cavities, depending on a relatively long time interval needed to reach a temperature range between $55-58^{\circ} \mathrm{C}$ (Panieri et al. 2008).

At the -290 Level, this temperature range was reached some 200,000 - 250,000 years ago: in fact the appearance of gypsum crystals inside the Ojo de la Reina cave (191 $\pm 13 \mathrm{kyr})$ provides an indirect proof of the beginning of the crystallization, at that time, in this deep phreatic environment. Although this process was interrupted several times by the oxide-hydroxide depositions, as testified by the black layers preserved within the gypsum wall (at the cave entrance), the deposition mainly

Fig. 7: Chronology of evolution stages of gypsum deposition inside the Naica caves: a) when the temperature of the hydrothermal fluids uplifting along the three main faults lowered below 100-120 ${ }^{\circ} \mathrm{C}$, hypogenic speleogenesis started at different levels inside the aquifer; b) the thermal water became supersaturated with respect to gypsum, and its nucleation took place extremely slowly in a phreatic environment at the -120 Level, where water first cooled down to the gypsum-anhydrite equilibrium temperature; c) huge selenite speleothems began to grow also at the -290 Level while fluctuation of the thermal groundwater in epiphreatic conditions produced gypsum corrosion phenomena at the -120 Level; d) a new period of phreatic gypsum nucleation was common in all caves; e) at the -120 Level further changes in the thermal watertable produced two cycles of epiphreatic phase of partial emersion with aragonite layer deposition on submerged gypsum crystals, alternated by completely saturated steps; f) a short period of meteoric seepage was active in a vadose fast-cooling environment with deposition of a thin calcite cover; $g$ ) the calcite deposition at the -120 Level stopped by the thermal groundwater level lowering while deeper caves were still in phreatic conditions; $h$ ) at the -290 Level gypsum growth went on until 1985 when a sudden change from deep phreatic to vadose conditions was caused by the depression cone associated with mine exploitation. 

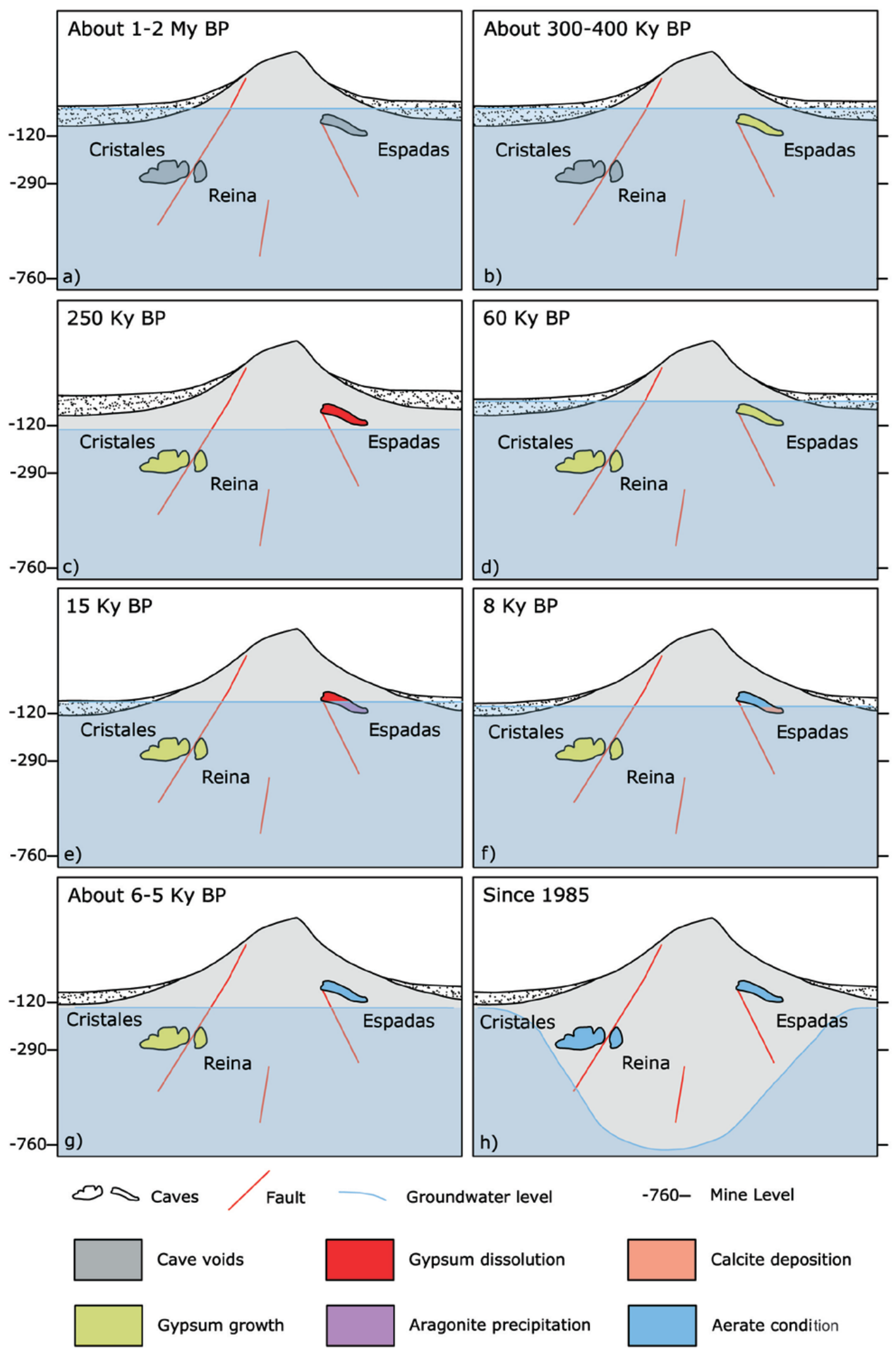

Gypsum dissolution

Calcite deposition 
occurred under phreatic conditions until 25 years ago when dewatering abruptly lowered the watertable below the -290 Level.

In spite of the purity of giant crystals of Cueva de los Cristales, the information recorded on the naturally broken samples we collected is not so clear, due to the ambiguity of stratigraphic position along the crystal length and even more to the wide gap in age of the inner core, which is dated between 106-260 kyr. At any rate it must be noticed that the obtained age interval is in agreement with the supposed starting of the gypsum evolution within the -290 Level.

As a consequence of the uncertainty about the age of the subsample taken close to the central part of the crystal, the corresponding growth rate is not well determined, ranging between 0.5 and $1.22 \mathrm{~mm} / \mathrm{kyr}$. However the comparison of these data to that obtained from the experimental growth rate $(0.4 \mathrm{~mm} / \mathrm{kyr})$ suggests that the "true" age of this sample is probably close to the oldest obtained value.

On the contrary, the growth rate of $1.45 \mathrm{~mm} / \mathrm{kyr}$, obtained by the other sample (collected within Cueva de los Cristales some $5 \mathrm{~cm}$ below its surface) is very different but, as pointed out before, it is related to the relatively recent stage in the development of the crystals. This suggests that although the development of the giant crystals was uninterrupted until the cave was drained, the growth was not uniform during time at least between about 50 and $35 \mathrm{kyr}$, and was affected by local factors, as suggested by the study of the fluid inclusions (Garofalo et al. 2010).

Large gypsum crystals developed also at the -120 Level in the Naica mine, but only a few of them are still preserved inside the Cueva de las Espadas. It was supposed that the deposition process was first active at this level, where the temperature cooled down earlier with respect to the deepest part of the system (Forti 2010; Forti \& Sanna 2010), and its evolution was controlled by subsequent fluctuations in the thermal groundwater level inside the cave, which led to several changes between phreatic and vadose environments (Forti 2007). Thus, it is hypothesized that the huge crystals grew over a time of around 300-400 thousand years, but almost all of these were re-dissolved during successive stages, and thus no dating of them is currently available. On the other side, a dating sequence can be obtained from the speleothem collected at the bottom of a small dry lake in this cave.
Its gypsum-aragonite-gypsum-aragonite-gypsum-calcite stratification allows reconstruction in detail of the latter steps in the evolution of the Naica thermal aquifer: after a new period of gypsum precipitation in phreatic conditions (dated back about $57 \pm 1.7 \mathrm{kyr}$ ago), an epiphreatic phase of partial emersion of the cave started about $14.5 \pm 4$ kyr ago (when the nucleation of aragonite occurred from thermal groundwater), and was followed by another period of complete saturation. All through this cycle, which was repeated two times during the cave evolution, some crystals (gypsum hooks) in the upper part of the cave were partially re-dissolved by condensation and bent by strong heating of their tips (Forti 2007) (Fig. 8).

Finally, since $7.8 \pm 0.04 \mathrm{kyr}$ a short period of meteoric water seepage occurred with the deposition of calcite as a consequence of the diffusion of $\mathrm{CO}_{2}$ from the cooling atmosphere into the gypsum-saturated water, as documented by the current calcium carbonate precipitation at the -590 Level (Forti et al. 2008). This step was active only for a very short span of time (the thickness of the calcite layer suggests that deposition lasted no more that 1-2 thousand years) after which the seepage of meteoric water stopped completely, thus inducing the end of the calcite deposition a few thousand years before the beginning of the mine activities.

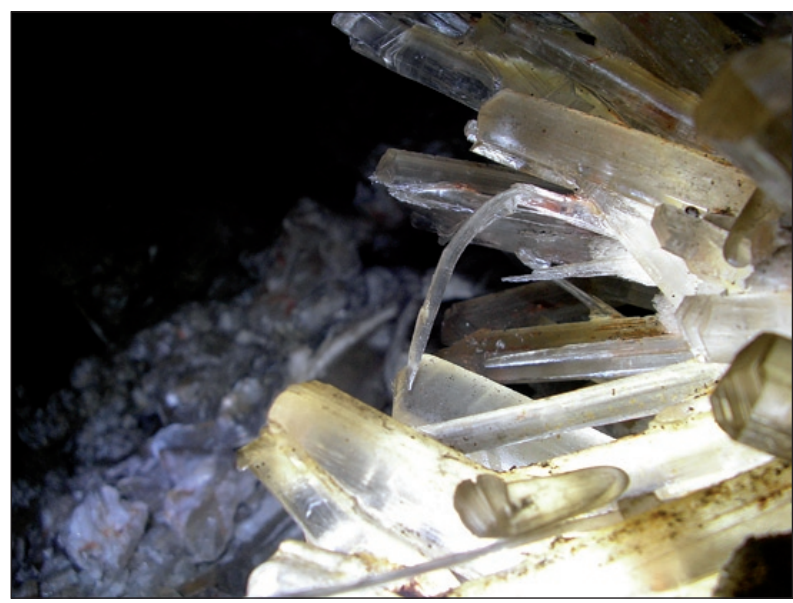

Fig. 8: Gypsum hooks from Cueva de las Espadas: re-dissolved and bent gypsum speleothems formed by condensation and strong heating of the crystal tips (Photo: Laura Sanna, La Venta \& S/F Archives). 


\section{ACKNOWLEDGEMENTS}

This research is a part of the "Naica Project" carried out by Speleoresearch \& Films of Mexico City in co-operation with La Venta Exploring Team of Italy and partly funded by the international collaboration project "Paleogyp" (CGL2006-01707/BTE Ministry of Science and Innovation, Spain). The author L.S. benefits from a training grant supported by the European Social Funding, through the Regione Autonoma della Sardegna ("Master
\& Back" Program - code T2-MAB-A2008-285). The authors thank Peñoles Company for allowing access inside the Naica Mine and for their support given during the field work. We greatly appreciated the comments provided by Jo De Waele and by the two reviewers (Dino Aquilano and the anonymous referee) that have been very useful in improving a first draft of this paper.

\section{REFERENCES}

Badino, G., A. Ferreira, P. Forti, G. Giovine, I. Giulivo, G. Infante, F. Lo Mastro, L. Sanna \& R. Tedeschi, 2009: The Naica caves survey.- In: White, W.B. (ed.) Proceedings of $15^{\text {th }}$ International Congress of Speleology "Karst Horizons", vol. III, pp. 1764-1769, Kerrville Texas-USA.

Badino, G. \& P. Forti, 2005: L'eccezionale ambiente della Cueva de los Cristales, Miniera di Naica, Messico: problemi genetici ed esplorativi. [The exceptional environment of the Crystal Cave, Naica Mine, Mexico].- Memorie Istituto Italiano di Speleologia, XVII, s. II, 87-92.

Badino G. \& P. Forti P, 2007: The Exploration of the Caves of the Giant Crystals (Naica, Mexico).- National Speleological Society News, 65, 2, 12-18.

Becker, J.S., 2003: Mass spectrometry of long-lived radionuclides.- Spectrochimica Acta, B, 58, 1757-1784.

Bernabei, T., G. Casagrande, A. Davila, A. De Vivo, A. Ferreira, G. Giovine, G. Infante \& F. Lo Mastro, 2009: The Naica Project.- In: White, W.B. (ed.) Proceedings of $15^{\text {th }}$ International Congress of Speleology "Karst Horizons", vol. I, pp. 283-288, Kerrville Texas-USA.

Bernabei, T., P Forti. \& R. Villasuso, 2007: A new type of gypsum speleothems from Naica (Chihuahua, Mexico): the sails.- International Journal of Speleology, 36, 1, 23-30.

Forti, P., 2006: Una foresta di cristalli di gesso nel profondo della miniera di Naica. [A forest of gypsum crystals in the depth of Naica mine].- Geoitalia 18, 29-34.

Forti, P., 2007: Studio della struttura interna di una stalagmite della Grotta delle Spade (Naica, Messico). [Study of internal structure of Sword Cave stalagmite (Naica, Mexico)].- Grotte e Dintorni, 6, 13, 3-20.
Forti, P., 2010: Genesis and evolution of the caves in the Naica Mine (Chihuahua, Mexico).- Zeitschrift für Geomorphologie, 54, sup. 2, 285-306.

Forti, P., E Galli. \& A. Rossi, 2007: The mineralogical study on the Cueva de las Velas (Naica, Mexico).- Acta Carsologia, 36, 2, 75-85.

Forti, P., E Galli. \& A. Rossi, 2008: Il sistema Gesso-Anidrite-Calcite: nuovi dati dalle concrezioni della miniera di Naica (Messico). [Gypsum-AnhydriteCalcite system: new data from speleothems of the Naica mine (Mexico)].- Memorie Istituto Italiano di Speleologia XX, s. II, 139-149.

Forti, P., E Galli. \& A. Rossi, 2009a: Minerogenesis in the Naica caves (Chihuahua, Messico).- In: White, W.B. (ed.), Proceedings of $15^{\text {th }}$ International Congress of Speleology "Karst Horizons", vol. I, pp. 300-305, Kerrville Texas-USA.

Forti, P., E Galli. \& A. Rossi, 2009b: Le grotte di Naica: non solo giganteschi cristalli di gesso. [Naica caves: not only giant gypsum crystals].- Rivista Italiana di Mineralogia, 3/2009,180-196.

Forti, P. \& F. Lo Mastro, 2008: Il laboratorio sperimentale di -590 nella Miniera di Naica (Chihuahua, Messico). [The experimental laboratory at -590 in the Naica Mine (Chihuahua, Mexico)].- Mondo Sotterraneo, 31, 1-2, 11-26.

Forti, P. \& L. Sanna, 2010: The Naica project. A multidisciplinary study of the largest gypsum crystal of the world.- Episodes, 33, 1, 23-32.

Foshag, W., 1927: The selenite caves of Naica, Mexico.American Mineralogist, 12, 252-232.

Gamble, V.C., 2008: An application of U-Th dating to lacustrine systems: lake Petén-Itzà, Guatemala and lake Malawi, Malawi.- Master thesis. University of Minnesota, pp. 98. 
Garcì-Riuz, J.M., R. Villasuso, C. Ayora, A. Canals \& F. Otàlora, 2007: The formation of natural gypsum megacrystals in Naica (Mexico).- Geology, 35, 4, 327-330.

Garofalo, P.S., D. Günther, P. Forti, S.-E. Lauritzen \& S. Constantin, 2007: The fluids of the giant selenite crystals of Naica (Chiuhahua, Mexico).- Proceeding of E.C.R.O.F.I., XIX European Current Research On Fluid Inclusions, 128.

Garofalo, P.S., M. Fricker, D. Günther, P. Forti, A.M. Mercuri, M. Loreti, B. Capaccioni, 2010: Climatic control on the formation of gigantic gypsum crystals within hypogenic caves (Naica mine, Mexico)?- Earth \& Planetary Science Letters, 289, 3/4, 560-569.

Goede, A., R.S. Harmon, T.C. Atkinson \& P.J. Rowe, 1990: Pleistocene climatic change in Southern Australia and its effect on speleothem deposition in some Nullarbor caves.- Journal of Quaternary Science, 5, 1, 29-38.

Hellstrom, J., 2003: Rapid and accurate U/Th dating using parallel ion-counting multi-collector ICP-MS.Journal of Analytical Atomic Spectrometry, 18, 1346-1351.

Hendy, C.H., T.R. Healy, E.M. Rayner, J. Shaw \& A.T. Wilson, 1979: Late Pleistocene glacial chronology of the Taylor Valley, Antarctica and the global climate.- Quaternary Research, 11, 172.

Ikeda, S. \& M. Ikeya, 1991: Electron Spin Resonance (ESR) signals in natural and synthetic gypsum: an application of ESR to the age estimation of gypsum precipitates from the San Andreas Fault.- Japanese Journal of Applied Physics, 31, L136-L138.

Lauritzen, S.-E., S. Constantin \& P. Forti, 2007: Chronology and growth rate of the Naica gypsum crystals. In: Forti, P. (ed.) Le Grotte di Naica: esplorazione, documentazione, ricerca. pp. 49-50, Bologna.

London, D., 2003: New "Cave of the Crystals" at Naica, Chihuahua, Mexico.- Earth Science Magazine, 24-27.

Lu, Y., 2009: Accurate and precise determination of isotopic ratios by MC-ICP-MS: a review.- Mass Spectrometry Reviews, 28, 990-1011.
Luo, S.D. \& T.L. Ku, 1991: U-series isochronal dating: A generalized method employing total-sample dissolution.- Geochimica et Cosmochimica Acta, 55, 555.

Mathew, G., T.K. Gundu Rao, P.S. Sohoni \& R.V. Karanth, 2004: ESR dating of interfault gypsum from Katrol hill range, Kachchh, Gujarat: Implications for neotectonism.- Current Science, 87, 9, 1269-1274.

Megaw, P.K.M., J. Ruiz \& S.R. Titley, 1988: High-temperature, carbonate-hosted $\mathrm{Pb}-\mathrm{Zn}-\mathrm{Ag}(\mathrm{Cu})$ deposits of northern Mexico.- Economic Geology, 83, 18561885.

Panieri, G., P. Forti, G. Gasparotto \& L. Soliani, 2008: Studio delle inclusioni solide presenti nei cristalli di gesso della grotta delle Spade (Naica, Messico). [Study of solid inclusions in gypsum crystals of Sword Cave (Naica, Mexico)].- Memorie Istituto Italiano di Speleologia, XIX, s. II, 335-343.

Peng, Z., W. Liu, P. Zhang, Z. Zhang \& J. Zhou, 2001: Precise timing of lacustrine gypsum in Luobubo, Xinjiang using the thermal ionization mass spectrometry U-series method.- Chinese Science Bulletin, 46, 1538-1541.

Richards, D.A. \& J.A. Dorale, 2003: U-series chronology and environmental applications of speleothems.- In: Bourdon B., Henderson G.M., Ludstrom C. \& Turner S. (eds.) Uranium-series Geochemistry. Reviews in Mineralogy and Geochemistry, 52, 407-460.

Sancho C., J.L. Peña, R. Mikkanc, C. Osácara \& Y. Quinif, 2004: Morphological and speleothemic development in Brujas Cave (Southern Andean Range, Argentine): palaeoenvironmental significance.- Geomorphology 57, 367-384.

Sanna, L., F. Saez, S.L. Simonsen, S. Constantin, J.M. Calaforra, P. Forti \& S.-E. Lauritzen, 2010: Uranium-series dating of gypsum speleothems: methodology and examples.- International Journal of Speleology, 39, 1, 35-46.

Shagun, C.L., 2001: Naica's subterranean marvels.- NSS News, 59, 6, 166-169.

Walker, M., 2008: Quaternary dating methods.- Wiley \& Sons, pp. 286, Chichester UK. 